\title{
MENCIPTAKAN GENERASI PEMUDA PEMUDI MUSLIM DALAM MENCIPTAKAN PELUANG USAHA KECIL DAN MENENGAH DALAM KONDISI WABAH COVID 19 DI YAYASAN AL IKHWANIA CINTA YATIM \& DHUA'FA CABANG PAMULANG BARAT
}

\author{
Hasundungan Pangaribuan ${ }^{1}$, Randhy Agusentoso ${ }^{2}$, Sinta Sulistiawati $^{3}$, \\ Windy Gustia Wardani ${ }^{4}$ \\ Dosen Fakultas Ekonomi Universitas Pamulang \\ Email : ${ }^{1}$ dosen01644@unpam.ac.id ${ }^{2}$ dosen01619@unpam.ac.id \\ dosen01876@unpam.ac.id ${ }^{4}$ dosen01579@unpam.ac.id
}

\begin{abstract}
ABSTRAK
Kegiatan pengabdian masyarakat merupakan salah satu komponen dalam Tridharma Perguruan Tinggi. Oleh karena setiap dosen memiliki kewajiban untuk melakukan pengabdian kepada masyarakat. Pengabdian yang dilakukan dalam proposal ini adalah pelatihan menciptakan peluang usaha kecil dan menengah dalam kondisi wabah Covid 19 di Panti Asuhan Ikhwaniyah Cinta Yatim dan Dhuafa Cabang Pamulang Barat. Oleh karena itu pengabdian ini berfokus pada pelatihan menciptakan peluang usaha kecil dan menengah dalam kondisi wabah Covid 1.

Selain itu, kegiatan pengabdian ini juga memiliki tujuan untuk mendukung program pemerintah untuk mengatasi permasalahan ekonomi nasional dikarenakan dampak wabah Covid 19. Adapun sasaran pada pengabdian masyarakat ini adalah warga di ponpes dalam rangka peningkatan masyarakat mandiri di Panti Asuhan Ikhwaniyah Cinta Yatim dan Dhua'fa Cabang Pamulang Barat. Program pengabdian ini dilaksanakan selama kurun waktu 3 hari.

Metode yang digunakan dalam pengabdian ini adalah pelatihan dan juga pendampingan tentang menciptakan peluang usaha kecil dan menengah. Hasil pengabdian ini menunjukkan bahwa warga ponpes sangat antusias mengikuti pelatihan ini. Lebih lanjut, dengan dilaksanakannya kegiatan pengabdian ini, masyarakat khususnya warga ponpes memiliki kemampuan untuk menciptakan peluang usaha kecil dan menengah dalam kondisi wabah Covid 19. Selain itu, kegiatan ini juga mampu memberikan dukungan agar ponpes terhindar dari pihak pihak yang tidak diinginkan.

Untuk kegiatan pengabdian selanjutnya diharapkan mampu memberikan pelatihan yang berkelanjutan yang memicu semangat warga ponpes untuk menghasilkan pendapatan sendiri demi meningkatkan kesejahteraan kehidupan warga ponpes.
\end{abstract}

Kata kunci : Menciptakan peluang usaha; Unit Usaha; Kapasitas; Pondok Pesantren

\begin{abstract}
Community service activities are one of the components in the Tridharma of Higher Education. Because every lecturer has an obligation to do community service. The dedication carried out in this proposal is training to create opportunities for small
\end{abstract}




\section{JURNAL ABDIMAS

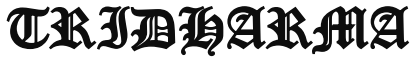 \\ $\mathfrak{H A}$}

P-ISSN 2615-6849, E-ISSN 2622-3686

Jurnal ABDIMAS Vol. 1,No. 3,September 2020,Hal (111-120)

@ Prodi Manajemen Fakultas Ekonomi Universitas Pamulang

Email: abdimasjurnal.unpam@ gmail.com Telp: (021) 741-2566

and medium enterprises in the conditions of the Covid 19 outbreak at the Ikhwaniyah Cinta Yatim and Dhuafa Orphanage of the West Pamulang Branch.

Therefore this service focuses on training to create opportunities for small and medium enterprises in the conditions of the Covid 1 outbreak. In addition, this service activity also aims to support government programs to overcome national economic problems due to the impact of the Covid 19 outbreak. The targets for this community service are residents in Islamic boarding schools in order to improve independent communities at the Ikhwaniyah Cinta Yatim and Dhua'fa Orphanage West Pamulang. This service program is carried out for a period of 3 days.

The method used in this service is training and also assistance on creating small and medium business opportunities. The results of this dedication show that the boarding school residents are very enthusiastic about participating in this training. Furthermore, with the implementation of this service activity, the community, especially members of the boarding school, has the ability to create small and medium business opportunities in the conditions of the Covid 19 outbreak. In addition, this activity is also able to provide support so that the boarding school can avoid unwanted parties.

For further community service activities, it is hoped that they will be able to provide continuous training that triggers the enthusiasm of the boarding school residents to generate their own income to improve the welfare of the residents of the boarding school.

Keywords: Creating business opportunities; Business unit; Capacity; Islamic boarding school

\section{PENDAHULUAN}

Sejak diumumkan oleh pemerintah tetang tersebarnya virus covid 19 pada awal bulan Maret 2020 dan semakin hari semakin meningkat dengan data resmi dalam situs www.covid19.go.id per tanggan 10 Agustus 2020 yang dapat dilihat gambar grafik dan data penyebaran adalah sebagai berikut ;

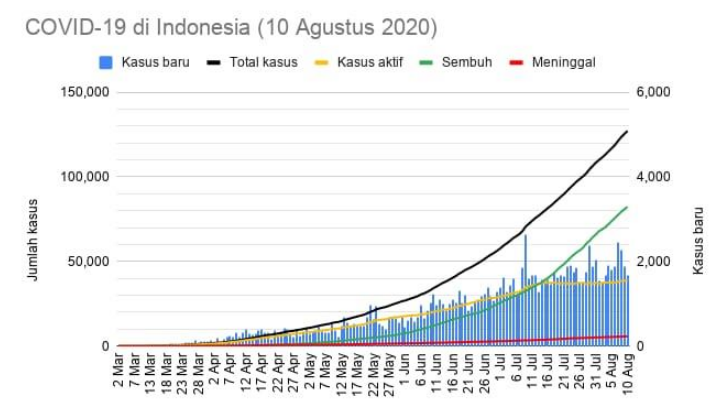

\section{Gambar 1. Grafik Penyebaran Covid 19 Per 10 Agustus 2020}

Dengan data penyebaran dengan rincian yaitu positif 1.687 meninggal 42 dan sembuh 1.284 sehingga total keseluruhan secara data nasional adalah sembuh 127.083, meninggal 5.765 dan sembuh 82.236.

Dan ini mengakibatkan roda perekonomian Indonesia secara khusus dan sekala Internasional pad umumnya mengalami resesi ekonomi sehingga diperlukan langkah-langkah kongrit dari pemerintah untuk mengatasi agat perekonomian Indonesia tidak mengalami keterpurukan. Sebagia masyarakat dan rakyat indonesia tidak boleh tinggal diam dalam menghadapi kesulistan ekonomi dengan menciptakan peluang bisns sehingga roda perekonomian tetap berjalan dan masyarakat tetap melakukan aktivias ekonomi dengan menggunakan protokol kesehatan yang dicanangkan oleh pemerintah.

Salah satu pengembangan bisnis di lingkugan yayasan panti asuhan Al Ikwaniyah Cinta Yatim dan Dhua'fa memiliki kiat-kiat untuk bertahan sehingga bisa menghidupi agar organisasi 


\section{JURNAL ABDIMAS

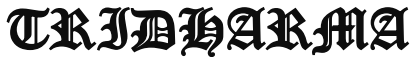 AIA}

dapat berjalan dengan bantuan dana yang ada dengan mengembangkan potensipotensi internal yang ada. Dari berapa penelitian terkait pengembangan yayasan panti asuhan yatim \& dhua'fa melalui pengelolaan pendanaan, antara lain : (Azizah, 2014) dalam penelitiannya mengenai pengelolaan unit usaha pada yayasan panti asuhan yatim \& dhua'fa, mengatakan bahwa proses manajemen unit usaha ekonomi di Anak - anak yatim piatu serta pengembangannya memiliki dampak positif untuk mencapai kesejahteraan bersama, yaitu ;

a) Terciptanya pola kader umat (santri dan masyarakat) yang mandiri dalam bidang ekonomi,

b) Terbentuknya yayasan panti asuhan yatim \& dhua'fa yang mandiri dalam bidang ekonomi,

c) Menjadikan yayasan panti asuhan yatim \& dhua'fa sebagai patner pemerintah, dan

d) Mampu mengangkat ekonomi umat (ekonomi masyarakat sekitar yayasan panti asuhan yatim \& dhua'fa maupun masyarakat secara luas).

(Rifqi, 2014) dengan penelitian tentang strategi pembiayaan mandiri anak - anak yatim piatu, mengatakan bahwa sumber pembiayaan yayasan panti asuhan yatim \& dhua'fa berasal dari antara lain : peserta didik, pemerintah, sumbangan BMT-UGT, BMT Maslahah, dan usaha kreatif yayasan panti asuhan yatim \& dhua'fa. Akan tetapi usaha kreatif merupakan bentuk dari pembiayaan yang bersifat mandiri bagi anak - anak yatim piatu, yang dapat digunakan untuk mengatasi permasalahan terkait ketidakpastian pendanaan yang diperoleh dari uang pembayaran santri atau peserta didik. Upaya dalam meningkatkan independensitas anak - anak yatim piatu tersebut, yaitu melalui pengembangan lembaga usaha mikro dalam lingkungan anak - anak yatim piatu. Hal ini disebabkan, karena anak - anak yatim piatu tidak ingin bergantung pada kucuran dana pemerintah, akan tetapi lebih menghidupkan potensi usaha mikro keuangan yang dimiliki oleh anak - anak yatim piatu. Bisnis online adalah kegiatan bisnis yang dilakukan di dunia maya dengan bantuan internet. Menjalankan bisnis online memerlukan media online sebagai wahana berbisnis. Ditengah Polemik Pandemi Covid-19, rantai pasokan logistik diharapkan meminimalkan pertemuan dan kerumunan pembeli. Dengan adanya Polemik Pandemi Covid-19 ini dapat mempengaruhi tingkat pendapatan penduduk Indonesia,yang mana banyak pekerja yang sudah tidak dipekerjakan lagi oleh perusahaannnya atau para pengusaha dan para pedagang kaki lima yang sudah tidak bisa menjualkan produk nya. Sehingga dengan adanya Polemik Pandemi Covid -19 masyarakat Indonesia berusaha menjadi kreatif dan inovatif untuk dapat menghasilkan pendapatan agar bisa bertahan hidup dengan cara menjadi pebisnis online. Maka dari pada itu muncullah bisnis-bisnis Online dengan berbagai produk, harga, promosi yang berbeda beda sebabagi contoh dengan melakukan Jasa titip satu dengan yang lainya. Dalam menjalankan bisnis online, Kita akan menjumpai berbagai tipe konsumen dari berbagai latar belakang yang berbeda, dan tidak semuanya bisa kooperatif. Menciptakan bisnis online yang sukses bukan tugas mudah. Pebisnis online tetap perlu berkompetisi dengan banyak bisnis lain untuk mendapat perhatian audiens target. Di luar sana menjadi dunia kompetisi yang sebenarnya. Dan untuk saat ini masa pandemic covid-19 bisnis online adalah cara yang baik dan peluang yang baik untuk menghasilkan uang. Yayasan AlIkhawaniyah Cinta Yatim \& Dua'fa perlu dibina untuk bisa memanfaatkan peluang bisnis online di masa Covid 19 ini dengan tema pengabdian kepada masyarakat yaitu : MENCIPTAKAN GENERASI PEMUDA/PEMUDI MUSLIM DALAM 


\section{JURNAL ABDIMAS

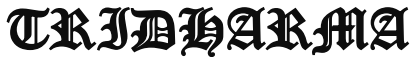

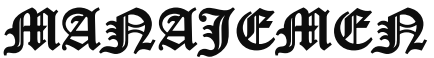

MENCIPTAKAN PELUANG USAHA

KECIL DAN MENENGAH DALAM KONDISI WABAH COVID 19" di JL.

Doktor Setia Budi No. 55A Pamulang 1 Barat - TANGERANG SELATAN".

\section{RUMUSAN MASALAH}

Berdasarkan latar belakang masalah yang sudah dipaparkan di atas bahwa dibutuhkan pengarahan serta pengimplementasian fungsi dan pengembangan bisnis Online dalam menyikapi wabah covid 19. Oleh karena itu kami merumuskan masalah dalam pengabdian kepada masyarakat adalahh sebagai berikut :

- Bagaimana kemampuan para anak anak panti asuhan memahanan tentang bisnis secara Online ?

- Bagiamana pengetahuan para anak anak panti asuhan dalam menjalankan proses seperti perencanaan, pengorgansasian, pengarahan, pengkoordinasian, pengawasan atau pengendalian dalam pengelolaan bisnis secara online dalam kondisi wabah covid 19 ?

- Bagaiamana kemampuan para anak anak panti asuhan dalam mempraktekkan sumber - sumber, pendanaan, pemanfaatan dana, pelaporan, pemeriksaan dan pertanggung jawaban dalam pengelolaan bisnis online dalam kondisi wabah covid 19 ?

\section{TUJUAN PELAKSANAAN}

- Memberikan pemahaman kepada anak - anak yatim piatu cara berbisnis secara online.

- Memastikan bahwa kegiatan seyogyanya dilakukan melalui proses perencanaan, pengorganisasian, pengarahan, pengkoordinasian, pengawasan atau pengendalian dalam pengelolaan Bisnis Online.

- Menyamakan persepsi beberapa kegiatan Bisnis Online berupa kegiatan memperoleh cara - cara mengelola Bisnis Online yang baik dan benar.

- Mempratekan pada sumber-sumber pendanaan, pemanfaatan dana, pelaporan, pemeriksaan dan pertanggung jawaban dalam pengelolaan Bisnis Online di lingkungan Panti Asuhan Al Ikhwaniyah Cinta Yatim \& Dhua'fa.

\section{MANFAAT PELAKSANAAN}

- Memberikan ilmu baru yaitu berbisnis secara online dalam memulai bisnis dalam konidisi wabah covid 19 kepada anak - anak yatim di yayasan al ikhwaniya cinta yatim dan dhua'fa.

- Menciptkan pebisnis dan entrepreneur baru yang berasal dari yayasan al ikhwaniya cinta yatim dan dhua'fa.

- Menambah kegiatan waktu luang di masa wabah covid 19 di lingkungan yayasan al ikhwaniya cinta yatim dan dhua'fa.

\section{TINJAUAN PUSTAKA}

\section{a. Pengertian Bisnis Online}

Sebelum virus corona menjadi pandemi, bisnis online sudah menjadi pilihan banyak orang karena sistemnya yang sangat fleksibel: transaksi melalui $m$-banking, berjualan di rumah, dan barang siap untuk kirim. Bisnis online tak hanya dapat berjualan barang, namun kita juga bisa menawarkan jasa, misalnya menyediakan kelas belajar online. Bisnis online merupakan bisnis yang bersifat mobile di mana dalam melakukan kegiatan bisnis dapat diakses kapan dan darimana saja, pembeli dapat memesan produk atau barang online dengan menggunakan media seperti Smartphone, laptop, notebook, komputer dan lain sebagainya.Penelitian ini dapat dianalisis melalui teori Ekologi Media. Ide utama dibalik teori ekologi media bahwa Mc Luhan melihat pengaruh 


\section{JURNAL ABDIMAS

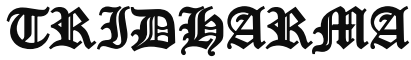

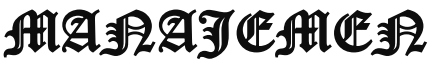

dari teknologi mediamasyarakat. Pemikiran Mc Luhan memiliki tiga asumsi yaitu: (Adul Karim Batubara, 2014: 134)

1) Media melingkupi setiap tindakan di dalam masyarakat yaitu media tidak dilihat dalam artian yang sempit seperti surat kabar/ majalah, radio, televisi, film atau internet tetapi Mc Luhan melihat apapun itu yang bisa digunakan sebagai medium oleh manusia.

2) Media memperbaiki persepsi kita dan mengorganisasikan pengalaman kita yaitu dimana teori ekologi media melihat media sebagai sesuatu yang memberi pengaruh kepada manusia secara langsung.

3) Media menyatukan seluruh dunia yaitu di mana Mc Luhan berasumsi bahwa setiap kejadian atau peristiwa yang terjadi di belahan dunia lain dapat diketahui atau menjalar ke belahan dunia lain dengan sebutan desa global. Melalui media online mahasiswa termotivasi untuk berbisnis guna menambah pendapatan dan melatih kemandirian.

Kalakota dan Whinston (1997) dalam Suyanto (2003:11) mendefiniskan EC (E-Commerce) dari beberapa perspektif berikut :

1. Berdasarkan perspektif komunikasi, EC merupakan pengiriman informasi, produk/layanan, atau pembayaran melalui lini telepon, jaringan komputer atau sarana elektronik lainnya.

2. Berdasarkan perspektif proses bisnis, EC merupakan aplikasi teknologi menuju otomatisasi transaksi dan aliran kerja perusahaan.

3. Berdasarkan perspektif layanan, EC merupakan satu alat yang memenuhi keinginan

\section{b. Pengertian Pemasaran}

Menurut Kotler \& Kellen (2008:5) Pemasaran adalah sebuah proses kemasyarakatan di mana individu dan kelompok memperoleh apa yang mereka butuhkan dan diinginkan dengan menciptakan, menawarkan dan secara bebas mempertukarkan produk dan jasa yang bernilai dengan orang lain. Sedangkan menurut William J. Stanton, (1984:7) yaitu: "Pemasaran adalah suatu sistem total dari kegiatan bisnis yang dirancang untuk merencanakan, menentukan harga, mempromosikan dan mendistribusikan barang-barang yang memuaskan keinginan dan jasa baik kepada para konsumen saat ini maupun konsumen potensial". Menurut Basu dan Hani (2004:4) Pemasaran adalah sistem keseluruhan dari kegiatan-kegiatan usaha yang ditujukan untuk merencanakan, menentukan harga, mempromosikan, dan mendistribusikan barang dan jasa yang dapat memuaskan kebutuhan baik kepada pembeli yang ada maupun pembeli potensial. Menurut Dayle dalam Sudaryono (2016:41), pemasaran adalah proses manajemen yang berupaya memaksimumkan laba (retutns) bagi pemegang saham dengan jalan menjalin relasi dengan pelanggan utama (valued customers) dan menciptakan keunggulan kompetitif. Adapun teori pemasaran Menurut Stanton dalam Tambajong (2013:1293), pemasaran adalah suatu sistem dari kegiatan bisnis yang dirancang untuk merencanakan, menentukan harga, mempromosikan dan mendistribusikan produk yang dapat memuaskan keinginan dalam mencapai tujuan perusahaan.

\section{c. Strategi Pemasaran}

Penyebaran covid-19 yang cepat memang merubah interaksi antara bisnis dan pelanggan. Banyak bisnis mulai merasa penurunan penjualan yang drastis atau bahkan tidak memiliki pelanggan sama sekali karena pelanggan sudah mulai beraktivitas di rumah mereka masing- 


\section{JURNAL ABDIMAS

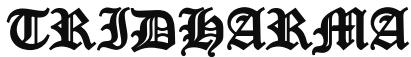

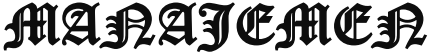

masing. Tetapi, keberlanjutan bisnis harus tetap dilakukan agar bisnis dapat dipertahankan. Mempertahankan bisnis yang berarti juga memperjuangkan penjualan selama wabah Virus Corona memang tidak mudah. Banyak yang bertanya- tanya bagaimana bisnis menjual produk di minggu atau bulan mendatang. Berikut beberapa strategi penjualan yang efektif untuk memastikan bahwa Anda tetap berjalan. Menurut Kotler \& Kellen (2008:43) Beberapa korpoersi memberikan banyak kebebasan pada unit bisnis mereka untuk menetapkan tujuan dan strategi penjulan serta lab mereka sendiri. Korporasi lainnya menetapkan tujuan untuk unit bisnis mereka tetapi membiarkan unit bisnisnya mengembangkan strategi sendiri. Korporasi lainnya menentukan tujaun dan berpatisipasi dalam mengembangkan strategi unit bisnis individu. Semua kantor pusat korporat melaksanakan empat kegiatan perencanaan :

1. Mendefinisikan nilai korporasi

2. Menentukan unit-unit bisnis strategis (SBU Strategic Business Units)

3. Menugaskan sumber daya pada setiap SBU.

4. Menilai peluang pertumbuhan.

Menurut Tjiptono (2000:6) Strategi pemasarann merupakan suatu manajemen yang disusun untuk mempercepat pemecahan persolalan pemasaran dan membuat keputusankeputusan yang bersifat strategis. Sedangkan menurut Buchari Alma (2008) strategi pemasaran adalah memilih dan menganalisa pasar sasaran yang merupakan suatu kelompok orang yang ingin dicapai oleh perusahaan atau usaha dan menciptakan suatu bauran pemasaran yang cocok dan dapat memuaskan pasar sasaran tersebut.

\section{METODE PELAKSANAAN}

\section{A. Kerangka Pemecahan Masalah}

Hal mendasar yang ditawarkan untuk ikut memecahkan masalah adalah melalui kegiatan pelatihan kepada para anak anak panti asuhan daerah tangerang selatan dikemas dengan nama kegiatan “

MENCIPTAKAN

GENERASI

PEMUDA PEMUDI MUSLIM DALAM MENCIPTAKAN PELUANG USAHA KECIL DAN MENENGAH DALAM KONDISI WABAH COVID 19" di JL. Doktor Setia Budi No. 55A Pamulang 1 Barat - TANGERANG SELATAN". Untuk lebih jelasnya dapat dilihat dalam skema di bawah ini :

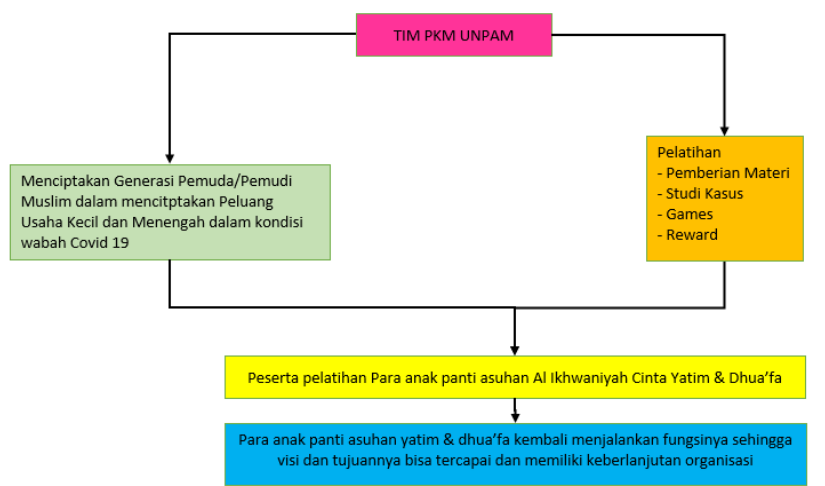

\section{Gambar 2. Kerangka Pemecahaan Masalah}

\section{B. Realisasi Pemecahan Masalah}

Universitas Pamulang (UNPAM) merupakan kampus yang berdiri di bawah naungan Yayasan Sasmita Jaya yang beralamat di Jl. Surya Kencana No. 1 pamulang dengan mengemban visi "Menjadi universitas peringkat 40 besar pada tingkat nasional yang dilandasi oleh nilai humanis dan religius pada tahun 2024" sedangkan Misi UNPAM yaitu :

- Menyelenggarakan pendidikan akademik, vokasi, dan profesiyang profesional berbasis humanis dan religius.

- Melaksanakan penelitian berbasis humanis dan religius yang menghasilkan inovasi untuk kesejahteraan masyarakat.

- Melaksanakan pengabdian kepada 


\section{JURNAL ABDIMAS

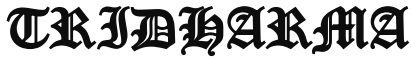 AtA}

masyarakat implementasi penelitian berbasis humanis dan religius.

- Menyelenggarakan peningkatan kualitas sumber daya manusia yang kompeten dan profesional.

- Menyelenggarakan kerja sama dalam negeri dan luar negeri berbasis saling menguntungkan.

Adapun visi dan misi UNPAM diatas merupakan penerapan dalam lingkup perguruan tinggi ada di dalam wilayah lingkungan Kopertis IV.

UNPAM membuka diri untuk melakukan berbagai kerjasama dengan berbagai pihak dalam rangka pengembangan ilmu, institusi, teknologi dan seni dalam rangka pelaksanaan Tri Dharma Perguruan Tinggi yakni: Dharma Pendidikan Pengajaran, Dharma Penelitian, dan Dharma Pengabdian Masyarakat. Dengan demikian azas pengabdian kepada masyarakat sesuai dengan azas kemanusia yang menekankan pada usaha pengembangan masyarakat sebagai subyek pembangunan. Kemudian pengabdian kepada masyarakat harus dilandasi pada kepercayaan dan kemampuan serta kekuatan masyarakat itu sendiri.

UNPAM sudah mempunyai jaringan dengan berbagai lembaga lain yakni pemerintah pusat, pemerintah propinsi, pemerintah kabupaten, dunia usaha, swasta maupun dengan masyarakat. Sudah selayaknya kehadiran perguruan tinggi agar dapat benar-benar dirasakan manfaatnya oleh masyarakat baik yang dekat maupun yang jauh.

Program pengabdian ini disusun berdasarkan hasil survey pendahuluan oleh TIM PKM ke lokasi Anak - anak yatim piatu Al Ikhwaniyah Cinta Yatim dan Dhua'fa Pamulang Barat serta wawancara kepada para santri anak - anak yatim piatu.

\section{Metode Kegiatan}

Metode yang akan digunakan dalam pengabdian masyarakat ini adalah melalui kegiatan:

1. Seminar dan presentasi

2. Pelatihan

Dengan menggunakan metode di atas agar bisa memecahkan masalah dengan melakukan kegiatan seperti pelatihan, games/permainan dan tutorial. Untuk lebih jelasnya Metode dan desain pemecahan masalah diatas dilakukan dengan berupa seminar, Pelatihan, Praktek dan evaluasi.

\section{HASIL DAN PEMBAHASAN}

Panti Asuhan Al-Ikhwaniyah Cinta Yatim \& Dhua'fa adalah sebuah lembaga yang bergerak dibidang pendidikan, sosial dan dakwah. Sejak kelahirannya diawal tahun 1970, lembaga ini sudah sangat dinantikan kehadirannya di tengah-tengah masyarakat yang ketikaitu masih sangat keterbelakangan baik dalam bidang, pendidikan, ekonomi, dan sosial. Melihat kondisi masyakat yang terbelakang tersebut, maka KH. Muhasyar H. Baran (Pimpinan) yang ketika itu baru saja pulang dari Panti Asuhan Temanggungan - Bogor, tergerak hatinya untuk memberikan penjelesan dan penerangan agama kepada masyarakat tentang penting membantu anak-anakk yatim dan dhua'fa. Dengan dukungan masyarakat dimulailah membuat sebuah adrama yatim putri. Namun ternyata pembangunan asrma yatim putri ini tidak berjalan sesuai harapan karena kendala yang dihadapi terutama keuangan yang menyebabkan terhentinya pembangunan tersebut dalam beberapa tahun. Pada tahun 1989 Yayasan Panti Asuhan AlIkhwaniyah diresmikan dan terdaftar dalam akte notaris. Berikut visi dan misi dari Yayasan Panti Asuhan Al Ikhwaniyah Cinta Yantim dan Dhua'afa adalah sebagai berikut :

Visi : Terwujud lembaga INTIFA (Cinta 


\section{JURNAL ABDIMAS

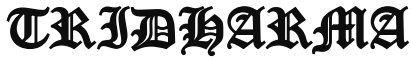 AlA}

Yatim \& Dhua'fa) yang profesional dan berkualitas

Misi : Memuwujudkan anak-anak yatim dan dhua'fa yang berkualitas melalui pendidikan formal dari keagamaan. Memberdayakan anak-anak yatim dan dhua'fa untuk tumbuh dan berkembang secara mandiri. Meningkatkan kualitas penghimpunan, pengelolaan, penyaluran dan pendayagunaan dana, zakat, infaq,shadaqah, wakaf secara amanah dan profesional.

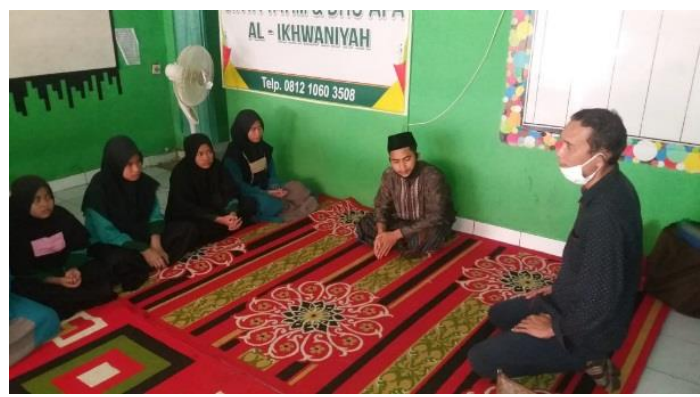

Dari hasil pelaksaan Pengabdian Kepada Masyakat dari Tim Panitia pelaksanaan melakukan evaluasi setelah kegiatan pelatihan kepada Para santri anak - anak yatim piatu yaitu dengan cara mengisi instrument yang disediakan oleh TIM Pengabdian Kepada Masyakart terkait bagaimanakah tanggapan para santri anak - anak yatim piatu jalan raya bsd buaran tangerang selatan terhadap kegiatan PKM yang dilakukan oleh Tim Dosen Manajemen Universitas Pamulang dapat dilihat pada table 4.2 Ketercapaian Target Luaran PKM adalah sebagai berikut :

\section{Tujuan PKM :}

- Memberikan pengetahuan tentang Bisnis Online berbasis pengelolaan keuangan di yayasan panti asuhan yatim dan dhua'fa

- Melaksanakan tata cara mengunakan metode menjalankan proses seperti perencanaan, pengorgansasian, pengarahan, pengkoordinasian, pengawasan atau pengendalian dalam pengelolaan Bisnis Online
- Memberikan pendampingan serta bimbingan teknis kepada santri tentang dalam mempraktekkan sumber - sumber pendanaan, pemanfaatan dana, pelaporan, pemeriksaan dan pertanggung jawaban dalam pengelolaan Bisnis Online

\section{arget PKM}

- Anak-anak mendapatkan pengetahuan tentang Bisnis Online

- Anak - anak Yatim berlatih menggunakan berubah pelatihan, games/permainan dan motivasi tentang perencanaan, pengorgansasian, pengarahan, pengkoordinasian, pengawasan atau pengendalian dalam pengelolaan Bisnis Online

- Anak- anak yatim dan dhua'fa dapat memahami bagaimana cara mengelola Bisnis Online mencari sumber-sumber pendanaan, pemanfaatan dana, pelaporan, pemeriksaaan dan pertanggung jawaban.
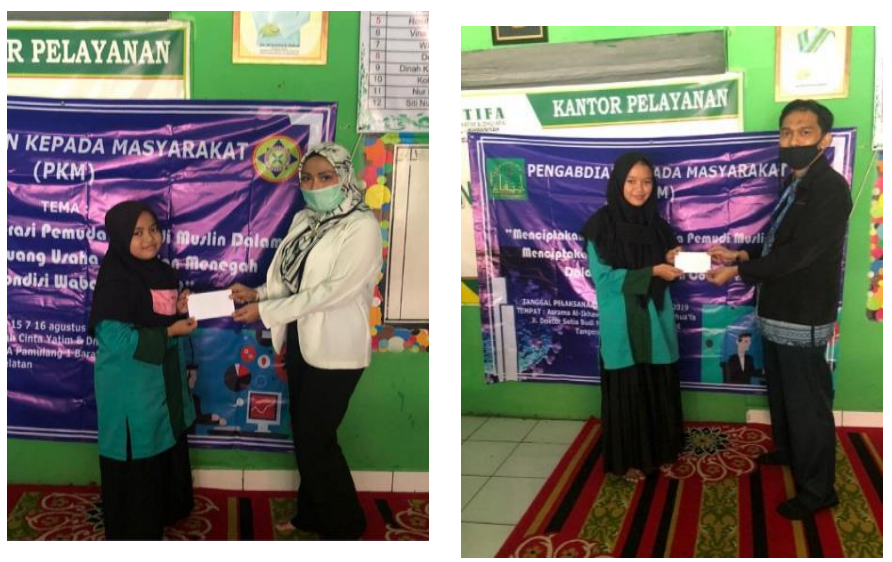

\section{Hasil Keluaran PKM}

- Tersampaikannya materi setiap anakanak yatim dan dhua'fa menerima materi dengan baik

- Tersampaikannya materi dimana anakanak yatim dan dhua'fa mengikut pelatihan, game/permainan dengan antusias, semangat dan menerima dengan suka cita.

- Tersampaikannya materi dengan baik memberikan materi yang disampaikan oleh nara sumber sehingga anak-anak 


\section{JURNAL ABDIMAS

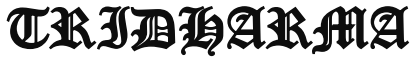

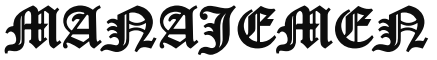

yatim dan dhua'fa dengan antusias dan semangat mengikuti pelatihan, games/pelatihan yang disampaikan oleh nara sumber .

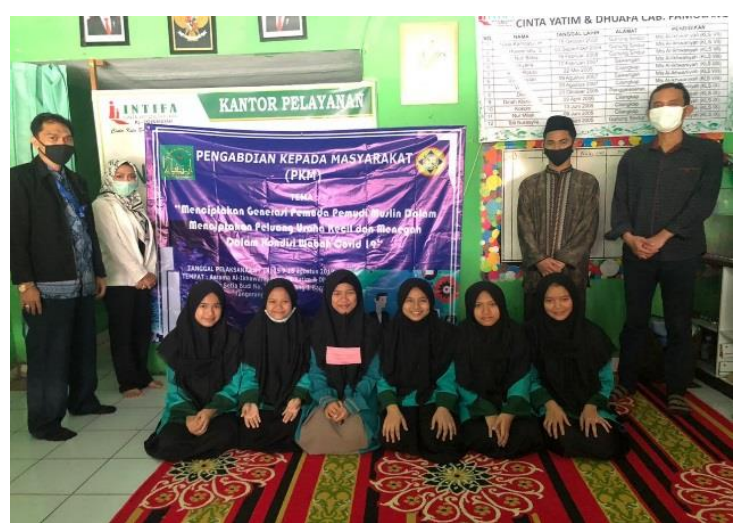

\section{KESIMPULAN DAN SARAN}

Hasil dari kegiatan Pengabdian Kepada Masyakart di Panti Asuhan Al Ikhwaniyah Cinta Yatim dan Dhua'fa Cabang Pamulang Barat kami bisa menarik kesimpulan bahwa dengan memanjatkan puji Syukur Alhamdulillah dapat berjalan lancar tanpa ada kendala yang berarti. Materi - materi yang dipersiapkan dapat tersampaikan oleh nara sumber/dosen dari Universitas Pamulang secara baik dan maksimal. Dari pengamatan Tim Pengabdian Kepada Masyakart dari tahapan- tahapan kegiatan yang telah dilakukan dalam kegiatan ini menunjukkan adanya peningkatan pemahaman santri panti asuhan dalam hal memahami, mempraktekan dan mampu mengelola manajemen keuangan dengan baik dan benar. Dilihat juga dari anank anak santri panti asuhan juga menunjukkan reaksi yang begitu semangat dalam mengikuti kegiatan serta pemahaman peserta pelatihan terhadap daya serap materi yang disajikan juga sangat baik. Kami melakukan evaluasi dengan memberikan beberapa pertanyaan intraktif dan permainan/games sehingga para anak - anak panti asuhat terlihat dari knowledge/pengetahuan yang dimiliki peserta pelatihan perihal subyek materi yang disampaikan. Selain itu, pada level psikomotorik atau ketrampilan menunjukkan hasil yang baik yakni mampu melakukan kegiatan praktik yang diberikan oleh Tim Pengabdian Kepada Masyarkat dengan baik. Bagi anak - anak yatim dan dhua'fa di Panti Asuhan Al Ikhwaniyah Cinta Yatim dan Dhua'fa Cabang Pamulang Barat, tingkatkan semangat belajarnya, jangan mudah puas, yang sudah baik ditingkatkan, yang belum baik senantiasa diperbaiki, serta perlu menjaga tensi semangat belajarnya hingga pada situasi dan waktu yang tidak ditentukan batas akhirnya. Bagi pendiri dan pengurus Yayasan, pendidikan berbasis teknologi bagi santri Panti Asuhan Al-Ikhwaniyah Cinta Yatim \& Dhuafa Cabang Pamulang Barat dan Tangerang Selatan secara terintegrasi perlu diperkuat lagi, sebab pendidikan berbasis teknologi menjadikan santri yang melek teknologi di era modern seperti saat ini.

\section{DAFTAR PUSTAKA}

Basu Swastha Dharmmesta, T. Hani Handoko, 2004, Manajemen Pemasaran "Analisa perilaku konsumen". Edisi ketiga cetakan ketiga. BPFE Yogyakarta, Yogyakarta

Buchari Alma, Kewirausahawan, (Bandung: Alfabeta, 2008), Cet. Ke-12, h. 195.

Geraldy Tambajong, 2013, Bauran Pemasaran Pengaruhnya Terhadap Penjualan Sepeda Motor Yamaha Di PT. Sarana Niaga Megah Kerta Manado, Jurnal EMBA, Vol.1 No.3 September 2013, Hal. 1291-1301

Irma Ade Peran Instagram Sebagai Media

Komunikasi Pemasaran Bisnis Online (Studi Deskriptif Kualitatif Pada Bisnis Online Beautyhomeshop) https://pdfs.semanticscholar.org/13 ba/e3e993221f844871442c93fe4fb 


\section{JURNAL ABDIMAS

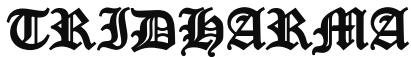

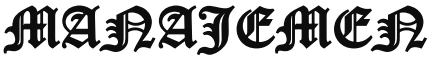

b024b0735.pdf

Izzati, Nurul Motif Penggunaan Gadget Sebagai Sarana Promosi Bisnis Online di Kalangan Mahasiswa UIN Sunan Kalijaga http://jurnalaspikom.org/index.php /aspikom/article/view/88/84

Kotler Philip \& Keller Kevin Lane (2008) Manajemen Pemasaran, Edisi 13 Penerbit Erlangga. Jakarta

Kusdiyanto. (2008). Pengelolaan Dana Yayasan Pondok Pesantren Yatim Hajjah Patisah ( Komplek Masjid Patisah Pajang Surakarta ). Warta, Vol. II(No. 2), 81-89.

Madjid, N. (1998). Bilik-Bilik Pesantren: Sebuah Potret Perjalanan. Jakarta: Paramadina.

Pasaribu, V. L. D., Susanti, F., \& Hartuti, E. T. K. (2019). Memotivasi Siswa dan Siswi SMK Letris Indonesia di Dalam Menentukan Pilihan Untuk Melanjutkan Pendidikan Atau Bekerja Setelah Lulus Sekolah. Jurnal Pengabdian Dharma Laksana, 1(2), 161-172.

Pasaribu, V. L. D., Agrasadya, A., Shabrina, N., \& Krisnaldy, K. (2020). MENJADI ENTERPRENEUR MUDA YANG MEMILIKI JIWA LEADERSHIP UNTUK MENGHADAPI MASA DEPAN. Abdi Laksana, 1(1).

Pasaribu, V. L. D., Elburdah, R. P., Sudarso, E., \& Fauziah, G. (2020). PENGGUNAAN MANAJEMEN WAKTU TERHADAP PENINGKATAN PRESTASI BELAJAR DI SMP ARAISIYAH. Jurnal ABDIMAS Tri Dharma Manajemen, 1(1).

Pasaribu, V. L. D., Sulaiman, S., Sutiman, S., Thaharudin, T., \& Purnomo, B. Y. (2020). PENGENALAN LETAK POSYANDU TERDEKAT DIKELURAHAN PISANGAN DENGAN MANAJEMEN PEMASARAN REVOLUSI 4.0 UNTUK MENINGKATKAN PENGETAHUAN MASYARAKAT LETAK DAN FUNGSI POSYANDU TERDEKAT PADA KELURAHAN PISANGAN. DEDIKASI PKM, 1(1), 105-110.

Pasaribu, V. L. D., Oktrima, B., Prabowo, B., Arianto, N., \& Haryoko, U. B. (2020). PROGAM PENDAMPINGAN DAN PENYELENGGARAAN PENDIDIKAN
ANAK PADA USIA DINI TERHADAP PRESTASI BELAJAR DILINGKUNGAN RT 020 RW 009. KEL GIRI PENI. KEC WATES. YOGYAKARTA. JURNAL LOKABMAS KREATIF, 1(1), 71-75

Rifqi, A. M. (2014). Strategi peningkatan dan pemanfaatan sumber pembiayaan mandiri di pondok pesantren. Manajemen Pendidikan, 24(No. 4), 325-328.

Stanton, William J. "Fundamentals of marketing" (1984), London, McGraw-Hill

Sudaryono. 2016. Manajemen Pemasaran Teori Dan Implementasi. Yogyakarta: ANDI

Suyanto, M. 2003. Periklanan pada eCommerce Perusahaan Top Dunia.Yogyakarta:ANDI.

Tjiptono, Fandy, (2000), strategi pemasaran, yogyakarta, ANDI

Yakin, N. (2014). Studi Kasus Pola Manajemen Pondok Pesantren AlRaisiyah di Kota Mataram. Ulumuna, Vol. 18(No. 1). 